\title{
SITUASI STRATEGI PROMOSI KESEHATAN DI VICO INDONESIA, TAHUN 2016
}

\author{
VICO INDONESIA HEALTH PROMOTION STRATEGY SITUATION IN 2016
}

\author{
Khansa Nadra \\ Departemen Promosi Kesehatan dan Ilmu Perilaku, \\ Fakultas Kesehatan Masyarakat, Universitas Airlangga, Surabaya. \\ Email: nadra.khansa@gmail.com
}

\begin{abstract}
This research is about health promotion strategy in Health department, VICO Indonesia in 2016. VICO or Virginia Company is an oil and gas company. The main office is located in Jakarta and for the production, VICO have four stations (field) that is located in East Kalimantan. This research will be spesifictly describe the health promotion strategy that have been done in Badak Field, Muara Badak, Kutai Kartanegara, East Kalimantan. The importance of strategy in health promotion is the reason why this research is done. Health promotion strategies are the means or steps needed to achieve or accelerate the health promotion goals. Ottawa Charter is basic of the health promotion strategy. The aim of this study is to describe the health promotion activities/programs in the Health department of VICO Indonesia, East Kalimantan 2016 based on five action means of Ottawa Charter. This research used a descriptive approach with data retrieval from observation, an interview, and supported by secondary data. VICO has a promotive and preventive section (promprev) inside the Health department, to take care of health promotion and prevention in VICO Indonesia. The results shows the activities that related to Ottawa Charter are the VICO president policy, facility compliance, education, socialization, inspection, training, as well as other activities related to health workers. The conclusion that can be drawn is the health promotion strategy at the VICO Indonesia Health department, East Kalimantan 2016, is up to standart with the five action means in Ottawa Charter
\end{abstract}

Keywords: health promotion, Ottawa Charter, VICO Indonesia

\begin{abstract}
Abstrak: Penelitian ini berisi tentang strategi promosi kesehatan yang ada di health department, VICO Indonesia pada tahun 2016. VICO atau Virginia Company adalah sebuah perusahaan Minyak dan Gas. Kantor pusat VICO terletak di Jakarta dan memiliki empat stasiun produksi (lapangan) yang terletak di Kalimantan Timur. Penelitian ini akan secara spesifik mendeskripsikan tentang strategi promosi kesehatan yang telah dilakukan di lapangan Badak, Muara Badak, Kutai Kartanegara, Kalimantan Timur. Pentingnya strategi dalam melakukan promosi kesehatan adalah alasan penelitian ini dilakukan. Strategi promosi kesehatan merupakan sebuah cara yang diperlukan untuk memperlancar atau mempercepat, dan memaksimalkan pencapaian tujuan promosi kesehatan. Salah satu strategi promosi kesehatan yang digunakan sebagai dasar adalah Ottawa Charter. Tujuan dari penelitian ini adalah untuk mendeskripsikan kegiatan/program promosi kesehatan di Health department VICO Indonesia, kalimantan timur tahun 2016 berdasarkan lima sarana aksi promosi kesehatan Ottawa Charter. Metode penelitian yang digunakan adalah deskriptif dengan pengambilan data dari hasil observasi, wawancara, dan didukung oleh data sekunder. VICO memiliki tim khusus dalam mengupayakan pencegahan penyakit dan promosi kesehatan, yaitu promotive dan preventive section (promprev). Hasil dari penelitian ini ditemukan beberapa kegiatan yang dilakukan, berhubungan dengan Ottawa Charter. Kegiatan tersebut adalah kebijakan presiden VICO, pemenuhan fasilitas, edukasi, sosialisasi, inspeksi, training, dan juga kegiatan lain yang berhubungan dengan kesehatan pekerja. Kesimpulan yang dapat ditarik dari penelitian ini adalah strategi promosi kesehatan di Health department VICO Indonesia, Kalimantan Timur tahun 2016, telah menjalankan lima sarana aksi dalam Ottawa Charter.
\end{abstract}

Kata kunci: promosi kesehatan, piagam Ottawa, VICO Indonesia

\section{PENDAHULUAN}

Tempat kerja atau perusahaan besar, cenderung untuk memiliki sumber daya manusia yang banyak. Memiliki pekerja yang sehat akan berpengaruh positif terhadap produktivitas perusahaan. Agar pekerja tetap sehat, pekerja harus bekerja dengan tubuh dan lingkungan yang sehat 
pula. Menurut Blum (1974), status kesehatan seseorang dipengaruhi oleh 4 faktor. Faktor tersebut adalah lingkungan, perilaku, fasilitas kesehatan, dan genetik. Kesehatan terkait erat dengan kondisi lingkungan, gaya hidup, dan cara kerja. Berdasarkan UU No 1 tahun 1970 Tentang Keselamatan Kerja, tempat kerja ialah tiap ruangan atau lapangan, tertutup atau terbuka, bergerak atau tetap dimana tenaga kerja bekerja, atau sering dimasuki tempat kerja untuk keperluan suatu usaha dan dimana terdapat sumber bahaya. Definisi tempat kerja menurut UU tersebut dapat diartikan bahwa tempat kerja ialah suatu bagian lokasi yang terdapat suatu usaha/aktivitas dan memiliki sumber bahaya.

VICO atau Virginia Indonesia Company, LLC adalah salah satu perusahaan Kontraktor Kontrak Kerja Sama (KKKS) ditunjuk BP MIGAS untuk melakukan proses pengeboran minyak dan gas bumi. VICO Indonesia yang sebelumnya dikenal sebagai HUFFCO, merupakan salah satu perusahaan Contractor Production Sharing minyak dan gas bumi yang berada di bawah naungan SKK MIGAS. Perusahaan VICO berdiri sejak tahun 1972 dan memiliki markas besar di Jakarta. VICO telah membuat lebih dari 470 sumur dan menemukan cadangan gas dengan jumlah total 14 trilyun kaki kubik, serta 457 juta lebih barel minyak. Stasiun produksi pertama yang dibangun adalah Badak pada tahun 1972, diikuti dengan Nilam pada tahun 1982, Mutiara pada tahun 1990, dan Semberah pada tahun 1991.

VICO telah mendapatkan beberapa penghargaan selama berdiri, baik dalam bidang kesehatan, lingkungan, maupun prestasinya sebagai perusahaan minyak dan gas bumi. VICO menerapkan pekerjaan dengan melindungi kesehatan dan keselamatan pada pekerja. VICO melakukan kegiatan pencegahan penyakit, promosi kesehatan, keselamatan kerja, dan pemeliharaan lingkungan. VICO memiliki standar/prosedur dalam melakukan sebuah pekerjaan. Sistem penanganan kesehatan pekerja dan pemberdayaan masyarakat di VICO sangat baik dan patut dijadikan pedoman ataupun contoh yang baik untuk perusahaan lainnya.
Promosi kesehatan merupakan sebuah proses yang memungkinkan setiap individu untuk meningkatkan kendali atas dirinya sendiri untuk meningkatkan kesehatan (WHO, Ottawa, 1986). Menurut Notoatmodjo (2005), promosi kesehatan adalah segala bentuk kombinasi pendidikan kesehatan dan intervensi yang terkait dengan ekonomi, politik dan organisasi, yang dirumuskan untuk memudahkan perubahan perilaku dan lingkungan yang kondusif bagi kesehatan.

Menurut Kurnawidjaja (2012), Promosi kesehatan pekerja didefinisikan sebagai upaya untuk mengubah perilaku yang merugikan kesehatan populasi pekerja, agar mendapatkan kondisi kesehatan dan kapasitas kerja yang optimal dengan cara mengombinasikan dukungan pendidikan, organisasi kerja, lingkungan dan keluarga. Dari beberapa definisi promosi kesehatan tersebut, dapat disimpulkan bahwa promosi kesehatan di tempat kerja adalah suatu upaya melakukan kegiatan manajemen dan pencegahan penyakit. Bentuk promosi kesehatan di tempat kerja cenderung banyak dilakukan dalam upaya melindungi keselamatan dan kesehatan pekerja dengan menggunakan peraturan, prosedur, dan juga pemenuhan sarana-prasarana, namun bentuk promosi kesehatan juga bisa dilakukan dengan kegiatan bersama atau sebuah program yang dilaksanakan oleh perusahaan.

Piagam Ottawa menyebutkan bahwa promosi kesehatan adalah proses yang memungkinkan seseorang untuk mengontrol dan meningkatkan kesehatan mereka (WHO, 1986). Tujuan promosi kesehatan yaitu perubahan perilaku. Perubahan perilaku dipengaruhi oleh banyak faktor. Metode dan teknik promosi kesehatan, adalah cara dan alat bantu yang digunakan oleh pelaku promosi kesehatan untuk menyampaikan pesan kesehatan (Notoatmodjo, 2005). Metode yang dilakukan dapat disesuaikan dengan kondisi lingkungan, masyarakat dan sumber daya dari pihak penyelenggara. Untuk memperoleh hasil yang optimal, perlu adanya penggunaan dan penyusunan strategi promosi kesehatan yang sesuai dengan kondisi lingkungan dan tidak menyalahi peraturan yang berlaku. 
Strategi promosi kesehatan merupakan cara atau langkah yang diperlukan untuk mencapai, memperlancar atau mempercepat pencapaian tujuan promosi kesehatan. WHO (1986) menyebutkan bahwa Ottawa Charter memiliki lima sarana aksi yang perlu dijalankan untuk membangun strategi promosi kesehatan yang baik. Sarana aksi tersebut adalah membangun kebijakan yang berwawasan kesehatan, menciptakan lingkungan yang mendukung, memperkuat gerakan masyarakat, mengembangkan keterampilan individu, dan reorientasi pelayanan kesehatan. Kelima sarana tersebut merupakan hasil dari konferensi internasional di bidang promosi kesehatan yang dilakukan di Ottawa pada tahun 1986.

Sarana aksi pertama, yaitu kebijakan berwawasan kesehatan ditujukan kepada para penentu kebijakan. Tujuan dari sarana ini adalah agar kebijakan yang dibuat akan menguntungkan kesehatan. Sarana aksi kedua yaitu menciptakan lingkungan yang mendukung, ditujukan kepada penyedia sarana prasarana atau pengelola. Tujuan dari sarana ini adalah untuk menunjang aktivitas masyarakat, khususnya dalam berperilaku sehat. Seperti penyediaan sarana olahraga, tersedianya air bersih, dsb. Sarana aksi ketiga yaitu memperkuat gerakan masyarakat. Sarana ini adalah sebuah upaya untuk memampukan individu maupun kelompok agar dapat meningkatkan kondisi kesehatannya secara mandiri. Kegiatan yang dilakukan dapat berupa kegiatan bersama seperti kegiatan bersih desa, car free day, dsb. Sarana aksi keempat adalah mengembangkan keterampilan individu. Keterampilan ini dapat diawali dengan pemberian edukasi tentang pemeliharaan kesehatan kepada masyarakat atau pekerja. Kesehatan masyarakat akan lebih mudah terwujud dengan banyaknya masyarakat yang terampil dalam memelihara kesehatan. Sarana aksi kelima adalah reorientasi pelayanan kesehatan. Sarana ini membuat masyarakat berpikir untuk tidak hanya menjadi pengguna pelayanan kesehatan, namun juga sebagai penyelenggara. Pelayanan kesehatan dalam sarana ini tidak hanya sebagai kuratif dan rehabilitative, namun juga promotif dan preventif.
Penelitian ini akan membahas mengenai strategi promosi kesehatan yang ada di health department, VICO Indonesia pada tahun 2016, khususnya yang dilakukan di Badak, dan akan dikaitkan dengan lima sarana aksi promosi kesehatan berdasarkan Ottawa Charter.

\section{METODE}

Penelitian ini menggunakan pendekatan kualitatif. Data yang digunakan adalah primer dan sekunder. Data primer diperoleh dari hasil observasi di area Badak, yang diizinkan untuk didatangi seperti Mess hall, Camp, kantor/gedung departemen, dan area Badak Plant. Data primer lain dikumpulkan dengan cara In depth interview kepada staff promprev Badak, staff promprev Jakarta, dan dokter yang sedang bertugas di Health department Badak. Peneliti juga berpartisipasi dalam beberapa kegiatan yang dilakukan di VICO. Data sekunder didapatkan dari data yang ada di VICO Indonesia. Data yang dapat dikumpulkan untuk penelitian ini adalah tabel kegiatan tahunan, foto kegiatan, beberapa absensi pekerja peserta kegiatan, dan email. Peneliti juga melakukan diskusi dengan pekerja baik dari Health department ataupun dari divisi/ departemen lain. Hal ini dilakukan agar dapat memperoleh gambaran yang lebih luas mengenai promosi kesehatan yang dilakukan oleh VICO Indonesia, khususnya di Health Department.

Metode lain yang digunakan adalah studi pustaka untuk memperoleh teori yang berkaitan dengan permasalahan yang ada dan mencoba untuk menyesuaikan teori dengan kenyataan yang terjadi di lapangan atau lokasi magang. Penelitian ini dilakukan selama 6 minggu, terhitung mulai tanggal 03 Februari 2017 hingga 16 Maret 2017. Lokasi penelitian berada di Jl. Cendrawasih no: 1, Muara Badak, Kalimantan Timur.

\section{HASIL PENELITIAN}

VICO Indonesia merupakan perusahaan minyak dan gas yang merupakan perusahaan kerja sama bagi hasil antara Indonesia dengan pihak British dan Italy yaitu, BP (British petroleum) dan ENI (Ente 
Nazionale Idrocarburi). Berdasarkan data profil perusahaan VICO yang didapatkan dari Human Resource Department, VICO sebagai perusahaan energi telah melakukan eksplorasi pada tahun 1970-an. VICO Indonesia telah membuat lebih dari 470 sumur dan telah menemukan cadangan gas dengan jumlah total 14 trilyun kaki kubik, serta 457 juta lebih barel minyak.

VICO Indonesia memiliki kantor pusat di Jakarta. VICO beroperasi di blok sangasanga Kalimantan Timur. Lokasi kegiatan perusahaan di Kalimantan Timur berada di Badak, Semberah, Nilam, dan Mutiara. Sumur Badak yang telah menjadi sumur pembuangan limbah cair di Indonesia yang pertama yang bertekad untuk mengurangi dampak produksi minyak dan gas bumi terhadap lingkungan hidup. Berdasarkan data jumlah karyawan VICO pada bulan Februari tahun 2017, jumlah pekerja di VICO secara total adalah 694 orang. Pekerja di wilayah Kalimantan Timur sendiri berjumlah 451 orang.

VICO Indonesia secara struktural dikepalai oleh seorang President Director. Presiden tersebut membawahi sembilan wakil presiden. Setiap wakil presiden bertanggungjawab dalam pengawasan satu divisi atau aset. Setiap divisi memiliki beberapa departemen yang diawasi oleh manajer. Salah satu divisi yang ada di VICO yaitu HSE (Health, Safety, And Environment) dan OI (Operation Integrity), yang pada tahun 2017 berubah menjadi HSE dan EA (Engineering Authority). HSE merupakan divisi yang bertanggungjawab terhadap pencegahan dan penanggulangan penyakit, dan kecelakaan kerja. Selain itu, HSE juga bertanggungjawab dalam pemeliharaan lingkungan agar dapat meningkatkan derajat kesehatan, khususnya pada pekerja VICO Indonesia.

HSE sendiri, terbagi menjadi tiga departemen yaitu Health, Safety, dan Environment. Setiap departemen memiliki program khusus dalam melakukan pencegahan dan penanganan terhadap gangguan kesehatan. Health department melakukan pencegahan terhadap penyakit akibat kerja, penyakit umum, dan melakukan penanggulangan penyakit dengan terapi fisik, obat, dsb. Safety department melakukan pencegahan terhadap kecelakaan kerja, sedangkan environment department melakukan pemeliharaan lingkungan untuk mencegah adanya gangguan kesehatan.

Health department merupakan salah satu bagian dari divisi HSE. Health department di Badak, memiliki klinik yang juga difungsikan sebagai kantor untuk departemen kesehatan di Badak. Klinik VICO di Kalimantan Timur terdapat di Badak dan Mutiara. Fasilitas pelayanan medis seperti First aid station (FAS) terdapat di Nilam dan Semberah. Klinik di Badak memiliki fasilitas laboratorium medis, X-Ray, Treadmill Test, dan MCU. Untuk emergency medical system VICO Indonesia memiliki fasilitas telefon umum di beberapa lokasi, dan bisa juga menghubungi lewat telefon genggam dengan nomer yang langsung terhubung ke klinik. VICO memiliki 4 ambulans dan fasilitas lain seperti BLS (Basic Life Support), AED (Automated External Defibrillator), dan first aider di beberapa lokasi. Selain itu VICO memiliki kebijakan golden period, yaitu penanganan darurat maksimal 1 jam setelah menghubungi, bantuan akan datang dan mendapatkan penanganan. VICO juga memiliki transportasi udara apabila dibutuhkan.

Health department dibagi menjadi 4 section. Occupational health dan industrial hygiene $(\mathrm{OH}-\mathrm{IH})$ melakukan tugas untuk pencegahan penyakit akibat kerja. Kegiatan yang dilakukan adalah review medical check up, job matching, health hazard identification, health risk assessment, health hazard monitoring and measurement, dan pelatihan $\mathrm{OH}-\mathrm{IH}$. Health benefit bertugas dalam bidang administrasi dan manajemen. Kegiatan yang dilakukan adalah reimbursement, invoice, hospital provider, dan health care budget. Medical service bertugas dalam bidang kuratif dan rehabilitatif. Kegiatan yang dilakukan adalah Pelayanan kesehatan primer, CDC (Chronic Disease Case) group meeting, Pelaksanaan medical check up, manajemen kasus, dan medical assistance. Promotive preventive section atau promprev, bertanggung jawab dalam melakukan beberapa kegiatan yang 
meliputi edukasi, sosialisasi, inspeksi, pelatihan, dan juga kegiatan lain yang berhubungan dengan kesehatan pekerja.

Promprev melakukan beberapa kegiatan yang bertujuan untuk meningkatkan kesehatan pekerjanya. Berikut adalah cuplikan in depth interview bersama staff promprev Badak "Kita di VICO ini ada namanya itu medical check up yang dilakukan setiap tahun. Nah dari setiap tahun itu kemudian kita memberikan rangking dengan menggunakan salah satu tools itu adalah..., Framingham kemudian muncullah faktor risiko. Dari faktor risiko itulah kemudian bagaimana sih kita bisa melakukan namanya treat kepada orangorang yang punya faktor risiko tinggi..." (DS, 40 Tahun). Cuplikan tersebut menunjukkan bahwa VICO memiliki dasar/ sebab dalam kegiatan yang dilakukan. Setidaknya ada sembilan kegiatan rutin yang dilakukan oleh promprev. Kegiatan tersebut adalah health info, health session, new me, CDC group meeting, first aid training, first aid box inspection, water sampling and analisys, dan pengendalian hama.

Health info adalah sebuah artikel berisi tentang masalah kesehatan dan pencegahan penyakit yang sedang tren, baik di ruang lingkup VICO, nasional, maupun internasional. Health info disebarkan via email kepada seluruh pekerja di VICO Indonesia. Penyebaran dilakukan satu kali setiap bulan, dengan tema yang berbeda. Tujuan health info adalah untuk meningkatkan pengetahuan dan kesadaran pekerja tentang pentingnya masalah kesehatan dan bagaimana cara mencegahnya.

Health session adalah sebuah seminar kesehatan yang dilakukan oleh VICO, dengan mengundang pembicara ahli dari rumah sakit yang merupakan partner kerja VICO. Tema health session akan ditentukan dengan melihat tren kesehatan pekerja di VICO. Health session diadakan 6 kali per tahun, dengan 3 topik yang berbeda. Tujuan health session adalah agar pekerja dapat memahami, mengerti dan sadar tentang masalah kesehatan, terutama untuk pencegahan penyakit, sehingga para pekerja tidak terlalu bergantung pada obat-obatan atau treatment medis.
Cooperate wellness program atau yang lebih dikenal dengan new me, merupakan program pemantauan kesehatan kepada para pekerja VICO dan kontraktor yang memiliki risiko obesitas dan memiliki riwayat penyakit kronis. Program ini bertujuan untuk menurunkan berat badan karyawan dan mengubah perilaku para pekerja, terutama pekerja yang sudah memiliki riwayat penyakit kronis, untuk dapat meningkatkan kesehatan dan kebugarannya. Perilaku yang ingin diubah dalam program ini adalah cara berolahraga serta penerapan pola hidup sehat. Berikut adalah cuplikan hasil in depth interview bersama staff promprev Jakarta “...Kita itu program weight-loss, pengurangan berat badan... Kita tentukannya itu dengan riset hasil medical check up. Ini kan programnya tahun 2015 di Jakarta. Kalau di Badak kan 2016." (SA, 30 Tahun). Peserta dianjurkan untuk melakukan aktivitas fisik sesuai dengan resep yang diberikan oleh dokter olahraga, dan melaporkan hasil langkah dari pedometer setiap minggunya. Selain itu, setiap minggu juga diadakan penimbangan berat badan, dan pengukuran lainnya untuk menentukan kebugaran peserta.

CDC group meeting adalah kegiatan promprev yang bekerja sama dengan medical services untuk melakukan diskusi kesehatan dan berbagi pengalaman antar karyawan VICO Indonesia yang memiliki kasus penyakit kronis. Berdasarkan hasil wawancara ditemukan bahwa kegiatan CDC dilakukan untuk menurunkan angka kesakitan karyawan di VICO. Berikut adalah cuplikan hasil wawancara bersama dokter yang bertugas di Health department "Karna kan banyak nih karyawan yang ee, sekarang udah pasang ring jantung, kemudian sudah di bypass, penyakit metabolisme, penyakit kronis kayak hipertensi, gula darah, yaa. Kemudian CAD, nah itu semuanya. Gimana caranya kita untuk menurunkan angka penyakit kalo kita bilang di VICO ini CDC namanya," (DT, 31 tahun). Tujuan diskusi ini adalah untuk mencapai perawatan optimal dan gaya hidup yang baik. Diskusi dan berbagi pengalaman ini dilakukan 2 kali setahun di klinik VICO Indonesia yang melibatkan dokter dan perawat sebagai fasilitator untuk memberikan saran dalam 
diskusi ini. Penyakit yang termasuk dalam CDC di VICO adalah hiperlipidemia, hipertensi, diabetes mellitus, penyakit arteri cardio, dan asam urat.

First aid training yang dilakukan oleh VICO adalah pelatihan bantuan hidup dan pertolongan pertama pada kecelakaan tahapan dasar. Pada pelatihan ini juga diajarkan beberapa pertolongan pertama untuk keracunan, gigitan ular, luka dan patah tulang, luka bakar, transportasi, dan triage Kegiatan ini diadakan setiap bulan atau tergantung kepada kecukupan kuota peserta (15-25 peserta). Sasaran dari pelatihan ini adalah seluruh pekerja VICO Indonesia, khususnya yang belum pernah training ataupun yang sudah ikut dalam waktu lebih dari 3 tahun terakhir. Berdasarkan partisipasi dan observasi dari peneliti dalam kegiatan training ini, peserta diharuskan untuk mencoba melakukan setidaknya resusitasi jantung paru-paru pada akhir training. Peserta juga melakukan pretest dan post test. Sehingga ada penilaian yang bisa dijadikan evaluasi pada training yang dilakukan.

First aid box atau kotak P3K merupakan fasilitas yang memiliki item untuk melakukan pertolongan pertama pada kecelakaan. First aid box inspection meliputi inspeksi dan pemeliharaan terhadap fasilitas kotak P3K yang disebar di berbagai tempat, khususnya tempat kerja yang jauh dari jangkauan medis/klinik. Kegiatan ini dilakukan setiap bulan di seluruh area kerja VICO Indonesia, Kalimantan Timur.

Kegiatan lain yang dilakukan yaitu canteen hygiene. Inspeksi higienitas kantin dilakukan untuk memastikan pengadaan makanan yang tidak membahayakan konsumen, menjaga kelangsungan bisnis dan memenuhi ketentuan hukum. Salah satu aktivitas yang dilakukan adalah pengawasan pengelolaan makanan di tempat kerja secara berkala sesuai dengan Peraturan Menteri Kesehatan No. 1096 tahun 2011 tentang Higiene Sanitasi Jasaboga. Pengawasan dilakukan dari mulai bahan makanan, peralatan dapur, proses pengelolaan, penyajian, sampai setelah makanan dikonsumsi. Makanan yang disajikan akan disisihkan sebagian untuk disimpan selama beberapa hari. Hal tersebut dilakukan untuk memeriksa kembali apabila ada penyakit yang terjadi akibat makanan/ minuman. Selain itu juga akan dilakukan investigasi apabila terjadi keracunan, diare, dan kasus lainnya. Program pelatihan juga diberikan kepada Manajer dan supervisor dari operasional katering, serta penjamah makanan, sehingga mampu mengidentifikasi potensi risiko serta melakukan tindakan koreksi yang diperlukan untuk memperbaiki kekurangan yang ada

Water sampling dan analysis adalah kegiatan pengambilan sampel air dan pemantauan kualitas air yang digunakan di area VICO Indonesia Tujuan dari pemeriksaan sampel air perpipaan ini adalah untuk memastikan bahwa kualitas air yang dihasilkan adalah kualitas yang baik sesuai dengan peraturan Permenkes 492/MENKES/ IV/2010 tentang syarat air minum. Pemeriksaan sampel air dilakukan setiap bulan dan diperiksa pada Laboratorium intern VICO Indonesia. Sampling air diambil dari 16 titik yang tersebar di area Badak, Nilam, Semberah, dan Mutiara. Setiap tiga bulan dilakukan juga pemeriksaan sampel air dari ke 16 titik yang sama, namun diperiksa pada Laboratorium Kesehatan Daerah Samarinda untuk cross check serta dilakukan pemeriksaan mikrobiologi.

Kegiatan pengendalian hama dan vektor dengan atau tanpa menggunakan pestisida, dilakukan sesuai dengan kontrak kerja sama antara VICO Indonesia dan perusahaan pengendali hama. Tujuan dari kontrol serangga, hama, dan vektor adalah untuk mencegah kerusakan bahan makanan dan bangunan serta mencegah penularan penyakit. Kegiatan ini meliputi penyemprotan, pengasapan, misting, rodent control, larvaciding, dan umpan. Pengontrolan terhadap hama ini dilakukan 2 kali setiap minggu di semua area VICO Indonesia.

Kegiatan yang dilakukan dalam upaya promosi dan pencegahan penyakit oleh Health department yaitu publikasi internet, bulletin board, sosialisasi dan kampanye, dan juga kegiatan bersama. Publikasi internet dilakukan dengan mengirimkan leaflet melalui help desk kepada seluruh karyawan dan kontraktor dengan email. Publikasi internet ini disampaikan secara 
berkala. Batasan minimal dalam pengiriman leaflet adalah sekali sebulan atau $12 \mathrm{kali}$ dalam setahun, dan tidak memberikan batasan jika mengirimkan lebih dari 12 publikasi internet dalam setahun. Selain itu ada Papan Bulletin Publikasi yang dibuat untuk mendukung publikasi internet. Hal ini dilakukan karena tidak setiap kontraktor dilengkapi dengan komputer dan akses email. Pekerja di lapangan atau rig (buruh, pembantu, dll) bisa mengakses informasi melalui selebaran yang menempel di papan pengumuman, poster, roll-up banner, dan pop-up display banner. Sebagian besar informasi di poster, roll-up dan pop-up display banner, berisi tentang kampanye tertentu atau sosialisasi, seperti hari Cuci Tangan Dengan Sabun Dunia, virus Zika, obesitas, dan sebagainya.

Promosi kesehatan juga dilakukan dengan sosialisasi dan kampanye dengan sesi kesehatan (health session/health talk). Sesi kesehatan bertujuan untuk meningkatkan pengetahuan karyawan, keluarga dan kontraktor tentang kesehatan, terutama mengenai gaya hidup sehat dan penyakit tidak menular (penyakit degeneratif). Sesi kesehatan dapat dilakukan dalam bentuk salah satunya yaitu diskusi kesehatan di setiap departemen. Diskusi ini diadakan setiap bulan secara bergilir di setiap departemen di VICO Indonesia. Selain itu ada seminar Kesehatan, yang dilakukan enam kali setahun dengan menetapkan 3 tema yang di lokasi seperti Balikpapan, Mutiara Field, Samarinda dan Badak Field. Sesi kesehatan juga dapat dilakukan dengan kegiatan Kampanye kesehatan seperti melakukan kegiatan promosi kesehatan untuk memperingati hari kesehatan. Contoh kegiatan kampanye yang telah dilakukan oleh VICO adalah melakukan pemeriksaan tekanan darah pada hari Hipertensi Sedunia, melakukan pemeriksaan kadar gula darah pada hari Diabetes Sedunia, dll.

Kegiatan bersama yang dilakukan oleh Health department dapat berupa event kesehatan di waktu tertentu seperti jalan sehat, pemeriksaan kesehatan gratis untuk karyawan dan kegiatan kesehatan lainnya. Health event dilaksanakan bersama dengan hari kesehatan seperti hari Hipertensi Sedunia, hari Diabetes Sedunia, dan sebagainya. Tujuan kegiatan ini adalah untuk meningkatkan kesadaran terhadap kesehatan, sebagai sarana exercise dan kesenangan bersama kepada para pekerja. Kegiatan ini dilakukan di Badak dan Mutiara.

Pada tanggal 21 November tahun 1986, WHO (World Health Organization) mengadakan konferensi internasional pertama di bidang promosi kesehatan. Konferensi yang diadakan di Ottawa, Kanada ini dihadiri oleh para ahli kesehatan dari seluruh dunia. Hasil dari konferensi ini adalah sebuah dokumen penting yang disebut Ottawa Charter (Piagam Ottawa). Piagam ini menjadi rujukan untuk berbagai Negara dalam hal promosi kesehatan. Indonesia juga merupakan salah satu Negara yang menjadi kan Piagam Ottawa sebagai rujukan dalam bidang promosi kesehatan. Hasil dari konferensi internasional ini adalah lima sarana aksi promosi kesehatan. (WHO, Ottawa, 1986).

Sarana aksi promosi kesehatan yang pertama yaitu membangun kebijakan yang berwawasan kesehatan (build health public policy). Sarana pertama ini adalah untuk menjadi kan sebuah kebijakan yang akan dikeluarkan, dapat menguntungkan kesehatan publik (WHO, Ottawa, 1986). Sarana ini ditujukan kepada para penentu kebijakan yang terkait. Kebijakan ini dapat berupa perundangan, peraturan, surat keputusan, dan sebagainya.

Sarana aksi promosi kesehatan yang kedua adalah menciptakan lingkungan yang mendukung (create supportive environment). Lingkungan yang mendukung ini dapat berupa sarana prasarana ataupun fasilitas yang mendukung terjadi nya perilaku yang sehat bagi pekerja ataupun masyarakat (WHO, Ottawa, 1986). Sarana ini ditujukan kepada pengelola tempat umum/ kerja tersebut agar dapat tanggap dalam menyediakan fasilitas yang dibutuhkan.

Sarana aksi promosi kesehatan yang ketiga yaitu memperkuat gerakan masyarakat (strength community action). Gerakan masyarakat ini bertujuan untuk memandirikan individu, kelompok, dan masyarakat ataupun pekerja agar dapat meningkatkan derajat kesehatannya (WHO, Ottawa, 1986). Sarana ini dilakukan agar kesadaran, kemauan, dan kemampuan 
masyakarat berkembang, sehingga masyarakat dapat secara proaktif dan mandiri meningkatkan kesehatan diri dan lingkungannya.

Sarana aksi promosi kesehatan yang keempat yaitu mengembangkan keterampilan individu (develop personel skill) (WHO, Ottawa, 1986). Memiliki individu yang terampil mengenai kesehatan, akan berdampak positif terhadap kesehatan masyarakat apabila diaplikasikan. Karena individu merupakan bagian dari masyarakat, dan semakin banyak individu yang mengaplikasikan, kesehatan masyarakat akan semakin meningkat. Mengembangkan keterampilan dapat dilakukan dengan cara memberikan edukasi tentang cara memelihara kesehatan, mencegah penyakit, mendeteksi dini, dan materi kesehatan lain yang dapat diaplikasikan. Tujuan dari sarana ini adalah agar masyarakat dapat memahami dan melakukan apa yang telah dipelajari.

Sarana aksi promosi kesehatan yang kelima adalah Reorientasi Pelayanan Kesehatan (Reorient Health Service (WHO, Ottawa, 1986)). Masyarakat memahami bahwa dalam pelayanan kesehatan ada penyelenggara kesehatan seperti petugas kesehatan dan pengguna pelayanan kesehatan yaitu masyarakat. Pemahaman seperti ini harus diubah atau reorientasi, bahwa masyarakat bukan hanya sekedar pengguna atau penerima pelayanan kesehatan, tetapi sekaligus juga penyelenggara pelayanan kesehatan. Pelayanan kesehatan harus melibatkan masyarakat bahkan memberdayakan masyarakat agar bersatu dalam meningkatkan derajat kesehatan. Begitu juga dengan pemikiran bahwa pelayanan kesehatan bukan hanya melakukan upaya kuratif dan rehabilitatif melainkan juga melakukan upaya promotif dan preventif.

Deskripsi ini dilakukan dengan mencari kegiatan yang dilakukan oleh Health department VICO Indonesia Kalimantan timur, yang terkait dengan lima sarana aksi dari Ottawa Charter. Deskripsi ini dikhususkan untuk melihat pada program/ kegiatan dipromprev dan juga kegiatan yang dilakukan secara internal pada tahun 2016. Hal tersebut merupakan batasan yang diberikan agar sesuai dengan tujuan, serta untuk mengurangi risiko adanya bias.

Kebijakan dan peraturan yang berada di VICO Indonesia selalu berlandaskan peraturan di Indonesia dan internasional. VICO memiliki prosedur dan juga peraturan dalam melakukan suatu kegiatan. Kebijakan tertinggi pada organisasi internal VICO adalah kebijakan presiden. Kalimat utama dari kebijakan tersebut adalah "We are committed to conduct our activities in a way which protects health and safety of people and the environment. Our goal is to have No Accident, No Harm to People and No Damage to The Environment". Kalimat tersebut bermakna bahwa VICO Indonesia berkomitmen untuk bekerja dengan cara yang dapat melindungi kesehatan manusia dan juga lingkungan.

Terdapat delapan poin dalam dokumen kebijakan presiden tentang HSE. Kebijakan yang berwawasan kesehatan terdapat pada poin pertama, keempat, keenam, dan ketujuh. Pada poin pertama dijelaskan bahwa bekerja dengan aman adalah kondisi kerja bagi semua orang yang bekerja dengan VICO. Pada poin ini dapat terlihat bahwa VICO menjadi kan keselamatan sebagai prioritas untuk pekerja. Pada poin keempat dijelaskan bahwa kita harus mengukur kinerja HSE terhadap tujuan yang terdefinisi untuk menjamin perbaikan yang berkelanjutan. Poin keempat secara tidak langsung dapat menjaga stabilitas kesehatan pekerja, karena dengan adanya pengukuran kinerja, akan mempermudah proses evaluasi dan perbaikan terhadap kegiatan yang dilakukan.

Pada poin keenam dijelaskan bahwa setiap orang memiliki kewajiban untuk menghentikan pekerjaan jika merasa kegiatan tersebut tidak aman. Pada poin ketujuh dijelaskan bahwa kita harus melakukan aktivitas dengan bertanggung jawab secara sosial dan lingkungan. Kebijakan pada poin enam dan tujuh ini 
menegaskan bahwa siapapun bertanggung jawab terhadap keselamatan diri dan sekitarnya

Kebijakan, peraturan, dan prosedur di VICO Indonesia dapat di akses dengan mudah di komputer pekerja. Untuk kebijakan presiden ini lebih mudah ditemukan karena terdapat media offline. Kebijakan presiden dapat ditemukan di berbagai tempat seperti pintu masuk VICO, klinik, tiap gedung departemen, dan gazebo. Hal ini dilakukan agar seluruh pekerja maupun pengunjung di VICO Indonesia dapat mengetahui tentang adanya kebijakan ini. Pengunjung juga akan diberikan informasi mengenai beberapa peraturan sebelum melakukan aktivitas di VICO agar pekerjaan yang dilakukan tidak memberikan dampak negatif terhadap pekerja. Pekerja yang mengunjungi area khusus juga akan diberikan beberapa informasi tambahan yang diperlukan dan sesuai dengan kondisi lapangan.

Penyediaan sarana prasarana, atau fasilitas yang mendukung terciptanya perilaku sehat bagi pekerja, pengunjung, bahkan masyarakat sekitar juga telah dilakukan oleh VICO. Berdasarkan hasil observasi, berikut adalah fasilitas yang berada di lingkungan internal VICO Indonesia:

Water treatment plant atau instalasi pengolahan air merupakan sebuah sistem yang digunakan untuk mengolah air dari kualitas baku atau influent yang kurang baik agar mendapatkan air pengolahan yaitu effluent, sesuai dengan standar yang ditentukan. Parameter fisik air dapat diukur dengan penglihatan, sentuhan, rasa, dan aroma. Parameter fisik yang diukur adalah kekeruhan, warna, aroma, rasa, dan suhu.

Parameter biologi diukur berdasarkan mikroorganisme yang berada di dalam air. Jumlah mikroorganisme yang berlebih di dalam air, akan mengganggu kesehatan bila dikonsumsi. Sehingga perlu adanya treatment. Begitu pula dengan senyawa kimia. Menurut Said (2010), beberapa logam dan senyawa beracun yang sering ditemukan pada air limbah industri adalah $\mathrm{Cr}, \mathrm{Ni}, \mathrm{Fe}, \mathrm{Mn}, \mathrm{Zn}, \mathrm{Cu}, \mathrm{Cd}, \mathrm{Ag}$, dan $\mathrm{Pb}$. Mengonsumsi air yang mengandung senyawa kimia berlebihan, akan berdampak buruk bagi kesehatan. Pengolahan dapat dilakukan dengan sistem filtrasi.

Kantin atau mess hall di VICO memiliki higienitas yang terjamin, karena adanya pengawasan secara berkala. Para penjamah makanan juga sudah teredukasi dan memiliki seragam khusus untuk bekerja. Makanan yang disediakan di kantin selalu bervariasi dan sesuai dengan waktu makan. Berdasarkan hasil observasi, sarapan, makan siang, dan makan malam selalu memiliki menu yang berbeda. Namun menu yang selalu ada pada setiap waktu makan adalah buah dan roti/kue. Saat sarapan menu yang selalu disajikan adalah nasi, bubur, sereal, telur, roti dengan selai, sandwich, dan menu lain yang bergantian seperti pancake, bihun, lontong, mie, dan sebagainya. Menu makan siang dan makan malam juga beragam, namun yang selalu ada adalah aneka olahan seafood, daging merah, ayam, salad, sayur, nasi, dan olahan kentang. Menu makan siang akan berbeda setiap harinya, begitu juga dengan makan malam. Setelah masuk mess hall, dapat terlihat display bar untuk memerikan contoh takaran makan yang sehat, selain itu juga disediakan selembar menu yang lengkap dengan kandungan gizi seperti energi (kalori), kolesterol, protein, dan kandungan lemak per porsi.

Kamar mandi kamar pekerja maupun toilet umum, rutin dibersihkan oleh petugas. Toilet umum dapat ditemukan di beberapa tempat seperti sport hall, mess hall, gazebo, gedung departemen, masjid dan juga di lapangan. VICO memiliki tipe kamar mandi yang berbeda pada beberapa kamar tidur. Namun ketersediaan air, tissue, sabun, dan kebersihan selalu dipantau oleh petugas. Beberapa kamar juga menyediakan water purify untuk menggosok gigi dan kumur.

Pemilahan tempat sampah di VICO Indonesia dibagi menjadi empat, yaitu hijau untuk organik, kuning untuk anorganik, merah untuk metal, dan hitam untuk limbah B3. Tempat sampah hitam hanya bisa ditemukan di lokasi tertentu seperti plant, rig, ataupun well. Di area kantor umumnya ditemukan tempat sampah berwarna hijau, kuning, dan merah. Kamar tidur umumnya memiliki 1 tempat sampah saja, dan akan dipisahkan oleh petugas pengangkutan 
sampah. VICO memiliki tempat khusus untuk pengolahan sampah. Sampah yang diolah di VICO adalah sampah metal. Pemilahan sampah dilakukan untuk memudahkan pendaur-ulangan sampah. Sampah yang menumpuk akan memiliki dampak buruk terhadap lingkungan dan jangka panjangnya akan berdampak pula terhadap kesehatan baik pekerja maupun masyarakat sekitar. Sampah organik apabila dikumpulkan akan lebih cepat membusuk dan untuk anorganik dapat dimanfaatkan untuk membuat kerajinan ataupun daur ulang.

Kotak P3K (pertolongan pertama pada kecelakaan) difungsikan sebagai fasilitas dalam tindakan pertolongan pertama. Tujuan dari pengadaan kotak P3K adalah sebagai langkah mengantisipasi cedera dan kondisi gawat darurat. Kotak P3K berada di lokasi yang jauh dari klinik dan first aid station. Isi dari kotak P3K berdasarkan Permenaker no 15 tahun 2008 tentang Standar Isi Kotak P3K adalah kasa steril, perban (lebar $5 \mathrm{~cm}$ ), perban (lebar $10 \mathrm{~cm}$ ), plester (lebar $1.25 \mathrm{~cm}$ ), plester cepat, kapas, kain segitiga/mittela, gunting, peniti, sarung tangan sekali pakai, sarung tangan sekali pakai berpasangan, masker, pinset, lampu senter, gelas cuci mata, kantong plastik bersih, Aquades $(10 \mathrm{ml}$ larutan saline), Povidon Lodin (60ml), alkohol 70\%, buku panduan P3K di tempat kerja, dan buku catatan dan daftar isi kotak P3K. VICO Indonesia memiliki beberapa tambahan di kotak P3K, seperti serum anti bisa Ular. Hal tersebut dilakukan karena area VICO di Kalimantan Timur banyak ditemukan ular yang memiliki bisa.

Menurut Kementerian Kesehatan dalam buku Pedoman Pengembangan Kawasan Tanpa Rokok tahun 2011, Kawasan tanpa asap rokok (KTR) adalah ruangan atau area yang dinyatakan dilarang untuk kegiatan merokok atau kegiatan memproduksi, menjual, mengiklankan, dan/ atau mempromosikan produk tembakau. Penetapan KTR tersebut merupakan upaya perlindungan untuk orang di lingkungan tersebut terhadap risiko ancaman gangguan kesehatan karena lingkungan tercemar asap rokok. Kawasan tanpa asap rokok di VICO berada di tempat yang tertutup, lokasi pengeboran, dan lokasi lain yang memiliki tanda larangan merokok. Selain itu di kamar tidur dan beberapa tempat lain juga disediakan smoke detector atau alat pendeteksi asap. Alat ini digunakan untuk mendeteksi terjadi nya api sedini mungkin. Merokok di ruangan yang memiliki alat pendeteksi asap ini akan memicu alarm kebakaran berbunyi, sehingga merokok di dalam ruangan di VICO Indonesia tidak diperbolehkan.

VICO Indonesia, Badak memiliki fasilitas olahraga indoor dan outdoor. Untuk indoor ada sport hall dan juga squash room. Gedung Sport hall menyediakan fasilitas untuk fitness, sauna, badminton, tenis meja, tenis, basket, volley, dan aerobic/ freeletics pada hari tertentu. Fasilitas outdoor yaitu basket, bola, tennis, volley, bersepeda, dan jogging. Tujuan dari adanya fasilitas olahraga ini adalah kesehatan, kebugaran, meningkatkan produktivitas pekerja, dan menguatkan kesehatan mental. Olahraga bersama dapat mengembangkan teamwork yang lebih baik, sehingga akan meminimalisir konflik di tempat kerja.

Bulletin board adalah salah satu wadah untuk menyebarkan informasi melalui media cetak seperti brosur/poster. Fungsi dari Bulletin board ini adalah sebagai sarana komunikasi dan pengembangan kreativitas. Selain itu bulletin board juga memiliki fungsi untuk memanfaatkan waktu luang dengan membaca. Bulletin board terletak di setiap departemen, dan juga di gazebo agar dapat di akses oleh pengunjung umum.

Pekerja di VICO Indonesia khususnya di Kalimantan Timur memiliki rasa kekeluargaan yang cukup tinggi. Hal ini dapat terlihat ketika peneliti diizinkan untuk mengikuti aktivitas mereka di luar jam kerja. Para pekerja aktif memberikan nasihat terkait dengan kesehatan rekannya. Selain itu ada para pekerja yang aktif membentuk sebuah kelompok formal maupun informal dalam bidang olahraga tertentu. Kelompok olahraga biasanya terbentuk dari kesamaan hobi dalam bidang olahraga seperti club tennis, squash, basket, sepak bola, badminton, sepeda, senam, dsb. Apabila rekannya tidak bergabung dalam club tersebut, pekerja VICO juga ada yang aktif mengajak rekannya untuk ikut melakukan kegiatan olahraga seperti senam, jalan sehat 
ataupun melakukan berbagai jenis aktivitas fisik di fitness center.

Selain itu VICO memiliki kegiatan bersama pada hari tertentu. Adanya event juga memperkuat hubungan antar pekerja, seperti adanya event freeletics, bulan $\mathrm{K} 3$, donor darah, dan kegiatan lainnya. VICO juga mendapatkan penghargaan dari Walikota Samarinda dan PMI (Palang merah Indonesia) sebagai koordinator donor darah di Samarinda pada tahun 2015 dan 2016. VICO merupakan pemegang rekor pendonor terbanyak pertama di Kota Samarinda pada tahun 2015 dan 2016.

Promprev dalam mengembangkan keterampilan pekerja di bidang kesehatan, melakukan kegiatan seperti Basic First Aid (BFA) training, canteen hygiene, dsb. Pada BFA yang diajarkan kepada pekerja adalah prinsip dasar pertolongan pertama, tugas First Aider, sistem sirkulasi jantung dan respirasi, panduan penanganan korban, dsb. Training ini juga memiliki materi khusus seperti penanganan pada gigitan ular, keracunan, patah tulang, luka bakar, serta transportasi dan triage. Pada akhir BFA training, seluruh peserta akan diminta untuk melakukan simulasi dan diberikan penilaian. $\mathrm{OH}-\mathrm{IH}$ section di Health department juga mengadakan pelatihan OH-IH untuk memberikan keterampilan di bidang pencegahan penyakit, khususnya penyakit akibat kerja. Kedua training tersebut juga melakukan pre-test dan post-test untuk melihat tingkat pengetahuan peserta dengan adanya training. Health department (promprev dan $\mathrm{OH}-\mathrm{IH})$ mengeluarkan leaflet secara rutin, dan mengadakan health session untuk menambah keterampilan pekerja di bidang kesehatan. Pada promprev, leaflet dan kajian yang diberikan adalah tentang penyakit secara umum dengan menyesuaikan tren yang ada. Sedangkan $\mathrm{OH}-\mathrm{IH}$ cenderung kepada penyakit akibat kerja. Berbeda dengan safety department yang lebih cenderung kepada kecelakaan kerja.

Health department tidak hanya menangani permasalahan kuratif dan rehabilitatif, namun juga memiliki kegiatan yang bersifat promotif dan preventif. Kegiatan tersebut dilakukan oleh $\mathrm{OH}-\mathrm{IH}$ dan promprev. Kegiatan yang dilakukan khususnya pada promprev yaitu water sampling and analysis, canteen hygiene, induction, pest control, new me, health leaflet, health session, dan CDC group meeting. Kegiatan tersebut dilakukan secara rutin dan di evaluasi dalam jangka waktu yang telah ditentukan. Untuk CDC Group meeting, pada tahun 2016 menjadi tidak aktif dan diganti dengan adanya program new me, yang salah satu tujuannya adalah untuk menurunkan penyakit degeneratif. Program new me pertama kali berjalan di kantor Jakarta pada tahun 2015, dan pada tahun 2016 dijalankan di Badak, lalu pada tahun 2017 program new me diadakan di Mutiara.

\section{KESIMPULAN}

Health department di VICO Indonesia, Kalimantan Timur, memiliki 4 section dalam melakukan kegiatan operasionalnya. Section tersebut adalah $\mathrm{OH}-\mathrm{IH}$ yang berperan dalam mencegah penyakit akibat kerja, dan health benefit dalam kegiatan manajemen dan administrasi, serta medical services yang terdiri dari curehab (curative and rehabilitative), dan promprev (promotive preventive) untuk pencegahan penyakit secara umum.

Pada promprev kegiatan yang rutin untuk dilakukan adalah health info, health session, new me, CDC group meeting, first aid training, first aid box inspection, canteen hygiene, water analysis, dan pengendalian hama. Media yang digunakan yaitu publikasi internet, sosialisasi dan kampanye, bulletin board, dan juga dengan kegiatan bersama.

Dari kegiatan yang dilakukan oleh promprev, dapat disimpulkan bahwa strategi promosi kesehatan di Health department VICO Indonesia, Kalimantan Timur tahun 2016, telah menjalankan lima sarana aksi dalam Ottawa Charter, yaitu kebijakan berwawasan kesehatan, lingkungan yang mendukung, memperkuat gerakan masyarakat, mengembangkan keterampilan individu, reorientasi pelayanan kesehatan.

\section{DAFTAR PUSTAKA}

Blum, Hendrik L. 1974. Planning for Health, Development and Application of Social 
Change Theory. New York: Human Science Press.

Kurnawidjaja, L.M. (2012) Teori dan Aplikasi Kesehatan Kerja. Jakarta: UI Press.

Notoatmodjo, Soekidjoe. 2005. Promosi Kesehatan Teori dan Aplikasi. Jakarta: Rineke Cipta.

Pedoman Pengembangan Kawasan Tanpa Rokok Kemenkes tahun 2011.

Peraturan Menteri Kesehatan Republik Indonesia Nomor 56 Tahun 2016 Tentang Penyelenggaraan Pelayanan Penyakit Akibat Kerja.

Peraturan Menteri Kesehatan No. 1096/ Menkes/PER/VI/2011 Tentang Higiene Sanitasi Jasaboga.
Peraturan Menteri Tenaga Kerja dan Transmigrasi No. PER 01/MEN/1981 tentang kewajiban.

Peraturan Menteri Tenaga Kerja No 15 tahun 2008 tentang standar isi kotak P3K.

Said, N.I. 2010. Metoda Penghilangan Logam Berat (As, Cd, Cr, Ag, Cu, Pb, Ni dan Zn) di dalam Air Limbah Industri.

UU No 1 tahun 1970 Tentang Keselamatan Kerja.

WHO. 1986. The Ottawa Charter for Health Promotion, Geneva: WHO, dari http:// www.who.int/health promotion/ conferences/previous/Ottawa/en/. 